\title{
Allium sativum aqueous extract does not have chemo-protective effect on etoposide induced therapy-related DNA damage leading to Acute Myeloid Leukemia in albino-wistar rats
}

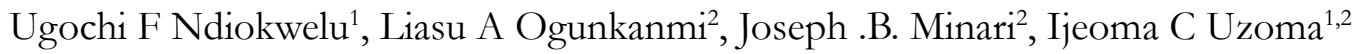

1. Molecular-Haematology Laboratory, Department of Medical Laboratory Science, Faculty of Health Sciences and Technology, College of Medicine, University of Nigeria Nsukka, Enugu Campus, Nigeria.

2. Department of Cell Biology and Genetics, Faculty of Science, University of Lagos, Akoka, Nigeria.

\author{
Author emails: \\ Ugochi F Ndiokwelu: uemereuwaonu@yahoo.com, Tel: +234 8164231661; Liasu A Ogunkanmi: Email: \\ logunkanmi@unilag.edu.ng, +234 8033564701; Joseph B Minari: Email: jminari@unilag.edu.ng, \\ +2348032488513; Ijeoma C Uzoma: E-mail address: ijeoma.uzoma@unn.edu.ng, Mobile: +234 7034959316
}

\begin{abstract}
Background: Therapy-related acute myeloid leukemia (t-AML) is a well-recognized clinical syndrome occurring in a significant fraction of patients who have undergone previous chemotherapy for a solid tumour.

Objectives: We aim to evaluate the effect of aqueous extract of fresh Allium sativum cloves on haematological parameters, bone marrow and DNA of etoposide treated albino wistar rats. Decoction method was used to prepare plant extracts and the rats were weighed and divided into experimental and control groups. Blood and bone marrow sample were analysed and DNA fragment analysis was carried out.

Results: There was progressive increase in the weight of animals that received distilled water only for the duration of the experiment while those that received etoposide only showed a sharp decrease in weight by the end of week 3 . There was no significant difference in the mean of the haematological parameters in the test and control groups except for platelet count. The bone marrow smears showed no prevention of erythroblast fragmentation by the extract, in the same vein, DNA damage was not abated.
\end{abstract}

Conclusion: Aqueous extract of fresh Allium sativum cloves may not be the option for the prevention of etoposide induced acute myeloid leukemia.

Keywords: Allium sativum aqueous, chemo-protective effect, acute myeloid leukemia, albino-wistar rats.

DOI: https://dx.doi.org/10.4314/ahs.v21i2.24

Cite as: Ndiokwelu UF, Ogunkanmi LA, Minari JB, Uzoma IC. Allium sativum aqueous extract does not have chemo-protective effect on etoposide induced therapy-related DNA damage leading to Acute Myeloid Leukemia in albino-wistar rats. Afri Health Sci. 2021;21(2). 673-682. bttps://dx.doi.org/10.4314/abs.v21i2.24

\section{Introduction}

Therapy related myeloid neoplasms (t-MN) occur due to direct mutational events of chemotherapeutic agents and radiotherapy ${ }^{1}$. Therapy-related acute myeloid leukemia/myelodysplastic syndrome (t-AML/t-MDS) is

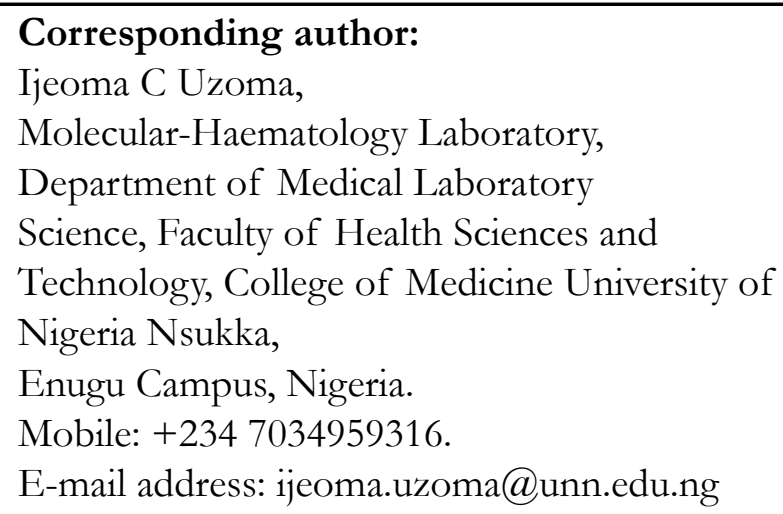

a well-recognized clinical syndrome occurring as a late complication following cytotoxic therapy ${ }^{2-6}$ in a significant fraction of patients who have undergone previous chemotherapy for a solid tumour. The peak occurrence time of $\mathrm{t}$-AML/t-MDS is 3 to 5 years after prior cytotoxic treatment, while the risk decreases markedly after the first decade 7 . Therapy-related myeloid neoplasms constitute approximately $10-20 \%$ of all cases of Acute myeloid leukemia and myelodysplastic syndrome ${ }^{8}$. Factors associated with an increased risk of t-MN include exposure to alkylating agents, topoisomerase II inhibitors, radiation therapy ${ }^{9-14}$ and older age at treatment, in addition to genetic susceptibility ${ }^{15,16}$. Also, $\mathrm{t}-\mathrm{MN}$ after anthracyclines and/or topoisomerase II inhibitors are associated with occurrence of AML- mye- 
loid/lymphoid leukemia (MLL) translocation at 11q23. Traditional herbal medicine could play pivotal roles in cancer treatment ${ }^{17}$. Allium sativum, commonly known as garlic, has been used as therapeutic medicinal agent for thousands of years to treat a variety of diseases such as cancer and cardiovascular diseases ${ }^{18}$. Therefore, we evaluated the effect of aqueous extract of fresh Allium sativum cloves on the haematological parameters, bone marrow and gel pattern of genomic DNA extracted from etoposide treated albino rats.

\section{Methods}

\section{Chemical used}

Etoposide VP-16 obtained from L'PaceMaker Pharmaceuticals Limited was used for the study and all other reagents were prepared in the laboratory.

\section{Laboratory animals used}

A total of 25 adult albino rats with average weight of 96$136 \mathrm{~g}$ were used and were obtained from the University of Lagos College of Medicine animal house. They were housed in standard clean rat cages at room temperature $\left(18-25^{\circ} \mathrm{C}\right)$ and fed with standard pellet rat chow (Korede Farms, Lagos-Nigeria) and tap water ad libitum. They were maintained under uniform conditions of natural photoperiod (12 hours' light-dark cycle) and humidity $(61-95 \%)$.

\section{Plant used}

The garlic bulbs used were purchased from Oyingbo market, Lagos state. Its cloves were identified and authenticated taxonomically at the Herbarium Unit of Botany Department of the University of Lagos and a voucher specimen number (LUH 7338) was deposited.

\section{Plant extract preparation}

Decoction method was used to prepare the plant extract. The garlic cloves were peeled, washed and blended using electronic blender (Freepour) and $1.2 \mathrm{~kg}$ of the ground garlic was put into a $5000 \mathrm{~mL}$ conical flask and $3 \mathrm{~L}$ of distilled water was poured in and mixed with ground garlic. The sample was then placed on a regulated water mantle and heated at $70^{\circ} \mathrm{C}$ for $15 \mathrm{mins}$. The heated preparation was then filtered using a $250 \mathrm{~mm}$ mesh followed by Whatman filter paper, $55 \mathrm{~mm}$ in diameter (Whatman Inc) and the residue taken through the same boiling process again. The combined filtrate was then concentrated in a water bath at $50^{\circ} \mathrm{C}$ leaving a paste-like garlic extract. Phytochemical screening employing standard procedure ${ }^{18}$ was carried out. Afterwards, stock solution of $10 \mathrm{~g} / 100 \mathrm{~mL}$ was prepared and stored in a refrigerator at $4^{\circ} \mathrm{C}$ till use ${ }^{19}$.

\section{Experimental design}

At the commencement of the experiment, the rats were weighed and classified into 5 groups, of 5 animals each. The classification was as follows;

Group RP: (Positive control) - Rats that received distilled water only

Group RN: (Negative control) - Rats that received 6 $\mathrm{mg} / \mathrm{kg}$ bw. /week of etoposide VP-16

Group RA: Rats that received $6 \mathrm{mg} / \mathrm{kg}$ bw. /week of etoposide VP-16 and $100 \mathrm{mg} / \mathrm{kg}$ bw. / day of extract Group RB: Rats that received $6 \mathrm{mg} / \mathrm{kg}$ bw. /week of etoposide VP-16 and $200 \mathrm{mg} / \mathrm{kg}$ bw. / day of extract Group RC: Rats that received $6 \mathrm{mg} / \mathrm{kg}$ bw. /week of etoposide VP-16 and $300 \mathrm{mg} / \mathrm{kg}$ bw. / day of extract

Induction was done by intraperitoneal injection of calculated doses (according to average body weight) of etoposide VP-16 (6 mg/kg bw. /week). This was administered to the 3 experimental groups and the negative control group.

Prepared aqueous Allium sativum extract was administered simultaneously following etoposide induction. Three different concentrations of extract $(100 \mathrm{mg} / \mathrm{kg}$ bw. /day, $200 \mathrm{mg} / \mathrm{kg}$ bw. /day and $300 \mathrm{mg} / \mathrm{kg}$ bw. / day) were prepared with respect to LD50 results as documented by Chris-Ozoko ${ }^{19}$. Each experimental group received one of the three concentrations by gavage using a cannula every day for 3 weeks. The positive control group (RP) received distilled water only.

\section{Experimental site and Ethical Statement}

The work was carried out in the animal house (Botanical garden) of the University of Lagos in accordance with the code of ethics of the World Medical Association (Declaration of Helsinki, 2008) for animal experiment with consent from the University of Nigeria Teaching Hospital, Health Research Ethics Committee (NHREC/05/01/2008B-FWA00002458IRB00002323) guidelines for experiment with whole animals.

\section{Complete blood count and bone marrow analysis}

At the end of 3 weeks, $2 \mathrm{~mL}$ of blood was collected from the eye vein of the animals in each group and analysed for complete blood count (CBC) using a fully automated 3-part haematology analyser (Alfa Swelab, Sweden). Afterwards, the animals were anaesthetized by inhalation of isoflurane and then euthanized by cervical dislocation. The femurs of the animals were then carefully removed and cleaned, the epiphyseal ends were cut off and solid bone marrow flushed unto a petri- 
dish using $0.5 \mathrm{~mL}$ saline, needle and syringe. Marrow suspension was centrifuged, and sediment used to prepare slides which were fixed in absolute methanol and stained with Wright's stain. The stained slides were then examined microscopically under 100x magnification with immersion oil.

\section{DNA extraction and electrophoresis}

Genomic DNA was also extracted from blood using lysis buffer, chloroform and cold ethanol then suspended in Tris-EDTA buffer and gel electrophoresis of extracted DNA was done using EDVOTEK M12 horizontal electrophoresis apparatus.

\section{Data analysis}

All statistical analysis were performed using Graph- pad prism version 7.02. Two-way analysis of variance (ANOVA) followed by Tukey's Multiple comparison test to determine which experimental group showed the most improvement in blood haematological parameters and least decrement in weights was calculated. Results were expressed as mean $\pm \mathrm{SD}$ and values of $\mathrm{p}<0.05$ were considered statistically significant.

\section{Results}

Results obtained from the qualitative phytochemical screening of aqueous Allium sativum extract are shown in Table 1. The phytochemical screening revealed the presence of saponins, flavonoids, tannins, alkaloids, molisch, proteins, reducing sugars and steroids with an acidic $\mathrm{pH}$. Anthraquinolones and terpenoids were absent.

Table 1: Qualitative phytochemical screening of aqueous extract of Allium sativum cloves

\begin{tabular}{lll}
\hline S. & Phytochemical & Indication in Aqueous Extract \\
No. & & \\
\hline 1 & Saponins & $(+)$ \\
2 & Flavonoids & $(+)$ \\
3 & Tannins & $(+)$ \\
4 & Alkaloids & $(+)$ \\
5 & Moilsch & $(+)$ \\
6 & Reducing sugars & $(+)$ \\
7 & Terpenoids & $(-)$ \\
8 & Proteins & $(+)$ \\
9 & Steroids & $(+)$ \\
\hline
\end{tabular}

Key: (+) Presence of phytochemical(s)

$(-)$ Absence of phytochemical(s)

Table 2 showed significant decrease $(\mathrm{p}<0.05)$ in weights and extract across the experimental groups with each of rats with simultaneous administration of etoposide new week.

Table 2: Effect of aqueous extract of Allium sativum cloves on average weight of etoposide treated rats

\begin{tabular}{|c|c|c|c|c|c|}
\hline Weeks & $\overline{R P(g)}$ & RN(g) & $\overline{R A(g)}$ & $\overline{R B(g)}$ & $\mathrm{RC}(\mathrm{g})$ \\
\hline Week 1 & $87.00 \pm 2.9$ & $138 \pm 8.3$ & $\begin{array}{l}117.00 \pm \\
2.8\end{array}$ & $\begin{array}{l}125.80 \pm \\
5.1\end{array}$ & $\begin{array}{l}140.00 \pm \\
6.0\end{array}$ \\
\hline Week 2 & $96.20 \pm 3.5$ & $\begin{array}{l}141.75 \pm \\
7.3\end{array}$ & $\begin{array}{l}115.66 \pm \\
2.9\end{array}$ & $\begin{array}{l}114.50 \\
\pm 10.0\end{array}$ & $\begin{array}{l}136.75 \pm \\
7.3\end{array}$ \\
\hline Week 3 & $109.40 \pm 4.6$ & $\begin{array}{l}116.66 \\
\pm 18.5\end{array}$ & $\neq$ & $\begin{array}{l}108.00 \pm \\
7.5\end{array}$ & $\begin{array}{l}133.3 \pm \\
8.0\end{array}$ \\
\hline
\end{tabular}

Key: $\neq-$ All Dead, values are means of 3 replicates \pm SD 
Post week one examination of experimental animals following administration of etoposide showed localized alopecia shown in Plate 1, which was generalized by the end of week two. There was a level of constancy in the average weight of animals that received distilled water only (RP) for the duration of the experiment as shown in Figure 1. Rats that received etoposide only (RN) showed a progressive decrease in average weight throughout the weeks. The experimental groups RA \& $\mathrm{RB}$ showed gradual decrease in average weight at the end of each week of administration while RC showed a progressive increase in average weight in the 3 weeks.

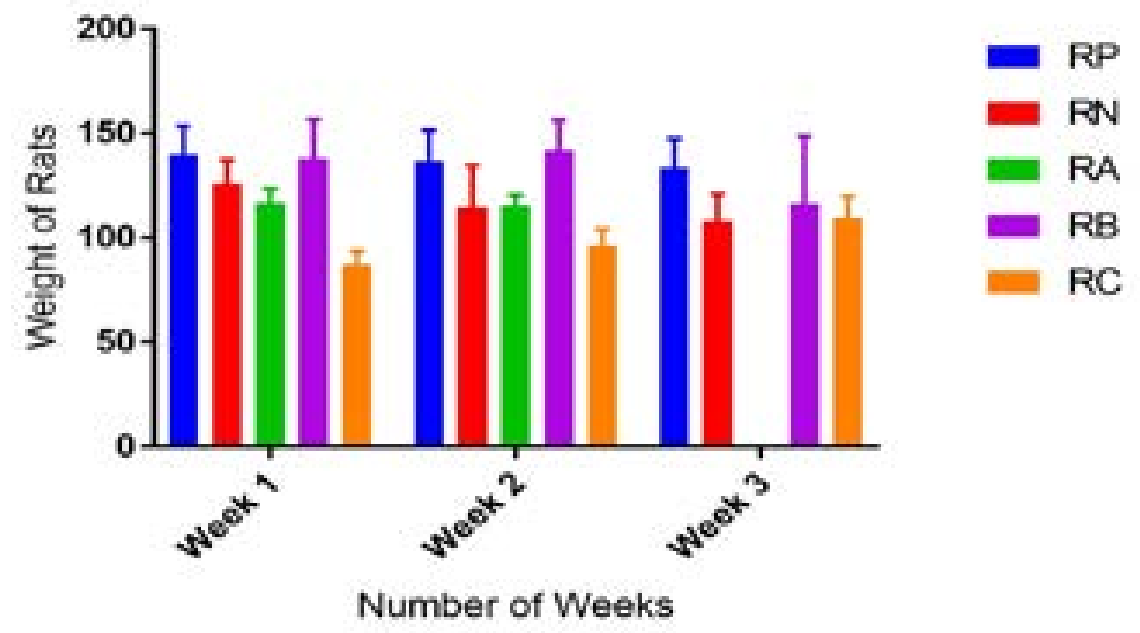

Figure 1. Effects of aqueous extract of Allium sativum cloves on weight trend of etoposide treated rats for 3 weeks

Legend:

RP: (Positive control) - Rats that received distilled water only

$\mathrm{RN}$ : (Negative control) - Rats that received $6 \mathrm{mg} / \mathrm{kg}$ bw./week of etoposide VP-16

RA: Rats that received $6 \mathrm{mg} / \mathrm{kg}$ bw./week of etoposide VP-16 and $100 \mathrm{mg} / \mathrm{kg}$ bw./day of extract

RB: Rats that received $6 \mathrm{mg} / \mathrm{kg}$ bw./week of etoposide VP-16 and $200 \mathrm{mg} / \mathrm{kg}$ bw./day of extract

$\mathrm{RC}$ : Rats that received $6 \mathrm{mg} / \mathrm{kg}$ bw./week of etoposide VP-16 and $300 \mathrm{mg} / \mathrm{kg}$ bw./day of extract

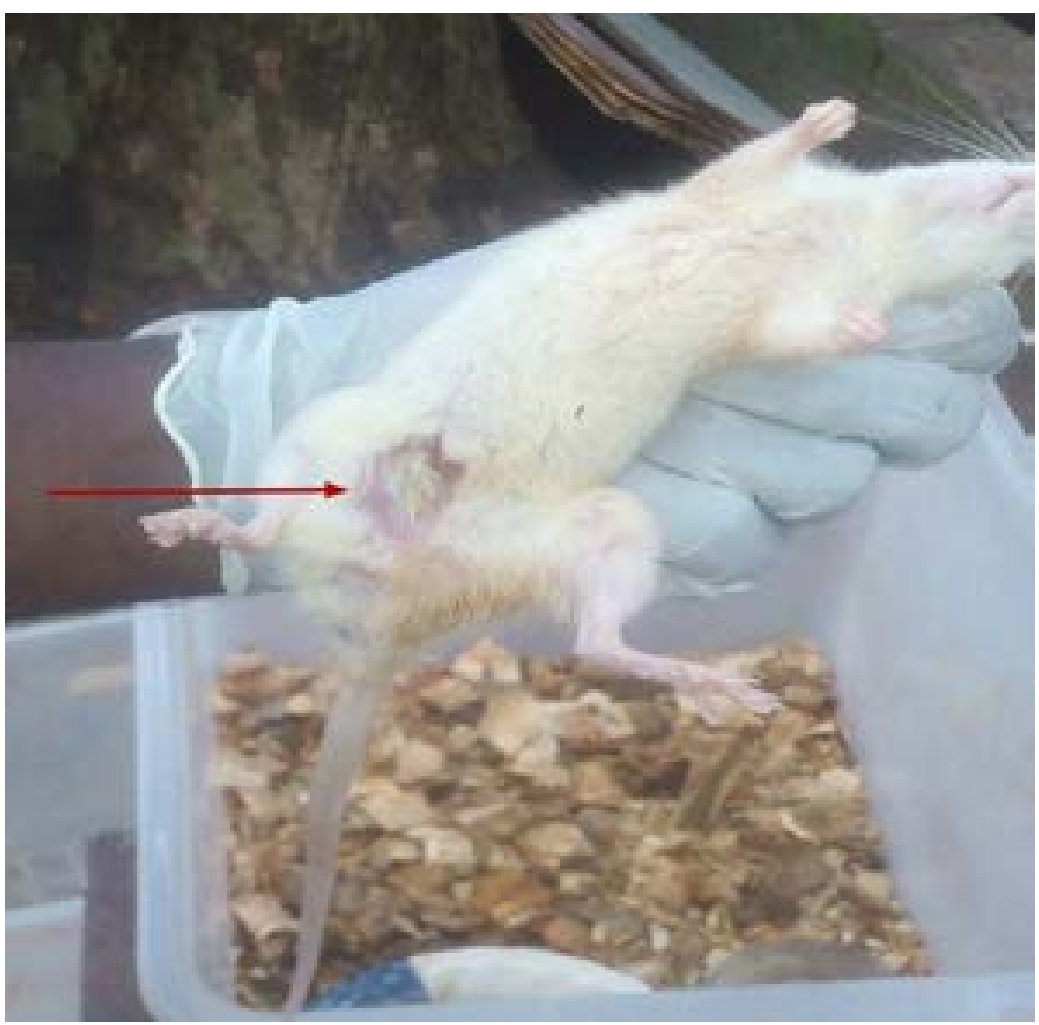

Plate 1. Etoposide induced-alopecia on peritoneal region of rats treated with Etoposide only. Arrow indicates the location of etoposide induced alopecia. 
Figure 2 showed zero deaths at the end of week one and at least two deaths recorded in each group at the end of week three. Plate 2 shows the result of the haematological examination of stained bone marrow smear from group RP. Haematological examination of smear seen in Plates 3 and 4 respectively revealed actively dividing megakaryocytes with normal nuclear budding, normal and active myeloid stem cells, erythroblasts with micro-nuclear fragmentation in rats from groups $\mathrm{RN}$ and $\mathrm{RB}$. Examination of smear from group $\mathrm{RC}$ is seen in Plate 5 and shows myeloblasts with undefined nuclear cytoplasm.

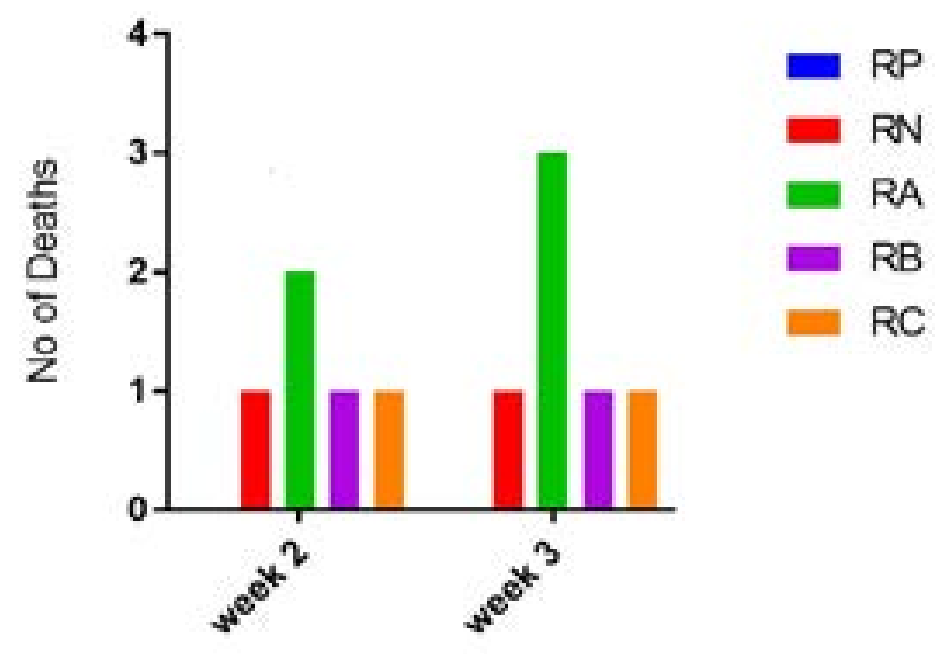

No of Weeks

Figure 2. Effects of aqueous extract of Allium sativum cloves on survival rate of etoposide treated rats.

Legend:

RP: (Positive control) - Rats that received distilled water only

RN: (Negative control) - Rats that received $6 \mathrm{mg} / \mathrm{kg}$ bw./week of etoposide VP-16

RA: Rats that received $6 \mathrm{mg} / \mathrm{kg}$ bw./week of etoposide $\mathrm{VP}-16$ and $100 \mathrm{mg} / \mathrm{kg}$ bw./day of extract

RB: Rats that received $6 \mathrm{mg} / \mathrm{kg}$ bw./week of etoposide VP-16 and $200 \mathrm{mg} / \mathrm{kg}$ bw./day of extract

RC: Rats that received $6 \mathrm{mg} / \mathrm{kg}$ bw./week of etoposide $\mathrm{VP}-16$ and $300 \mathrm{mg} / \mathrm{kg}$ bw./day of extract

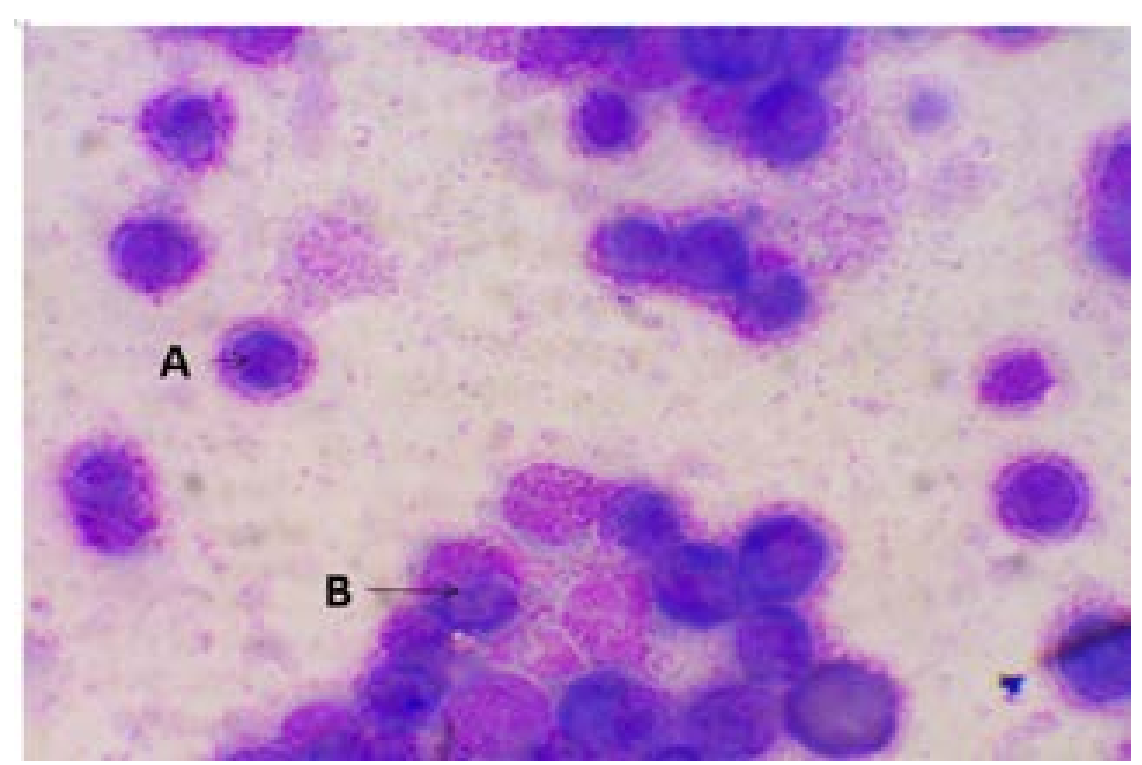

Plate 2: Bone marrow smear stained with Wright's stain from group RP (X100). RP: Rats administered with distilled water only. A. Basophilic Erythroblast. B. Megakaryocyte with normal nuclear budding. Megakaryopoiesis is active with normal nuclear budding. Myelopoiesis is active as well as erythropoiesis, basophilic erythroblast (shown with the arrow) appear to have normal morphology. 


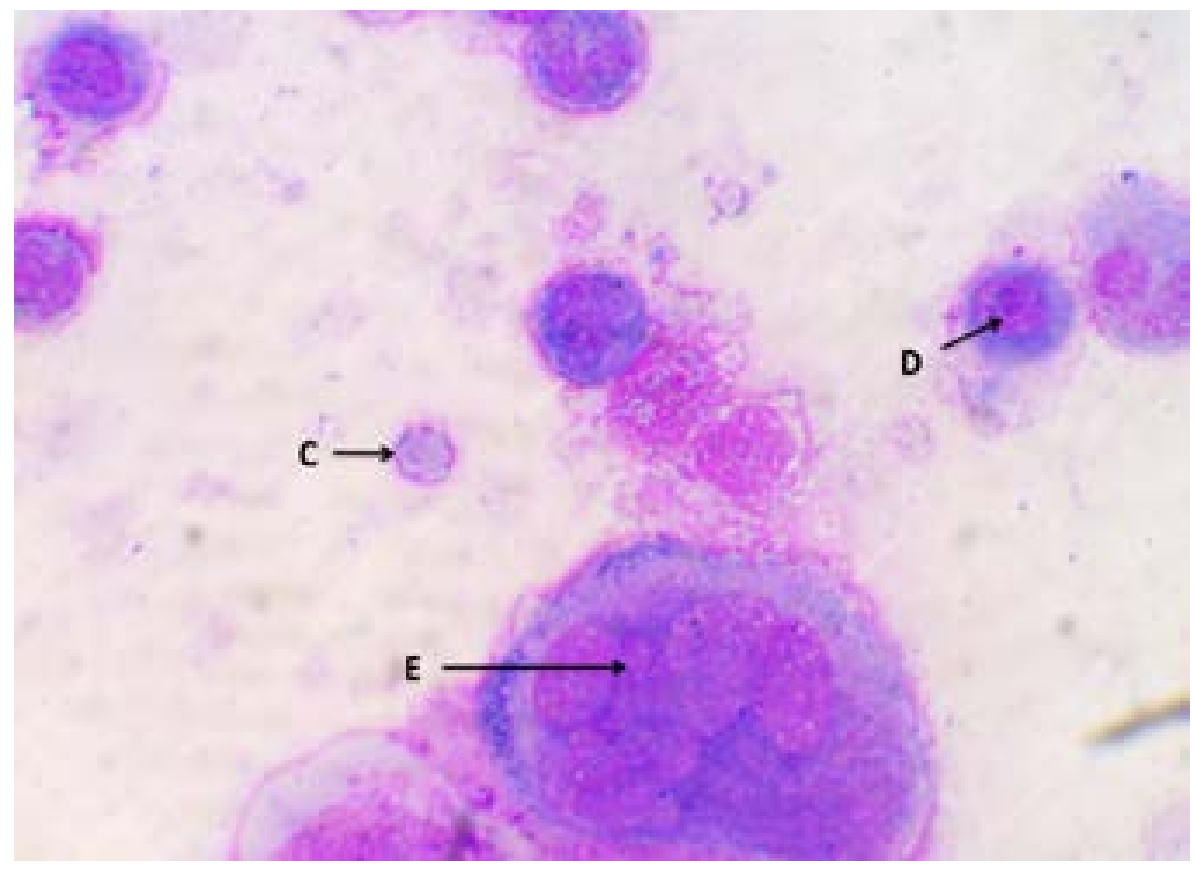

Plate 3: Bone marrow smear from RN showing erythroblast with micronuclear fragmentation and highly active megakaryocyte (Wright's stain X100). RN: Rats that received $6 \mathrm{mg} /$ week of etoposide VP-16. C. Erythroblast with micro-nuclear fragmentation. D. Small lymphocytes. E. Highly active megakaryocyte.

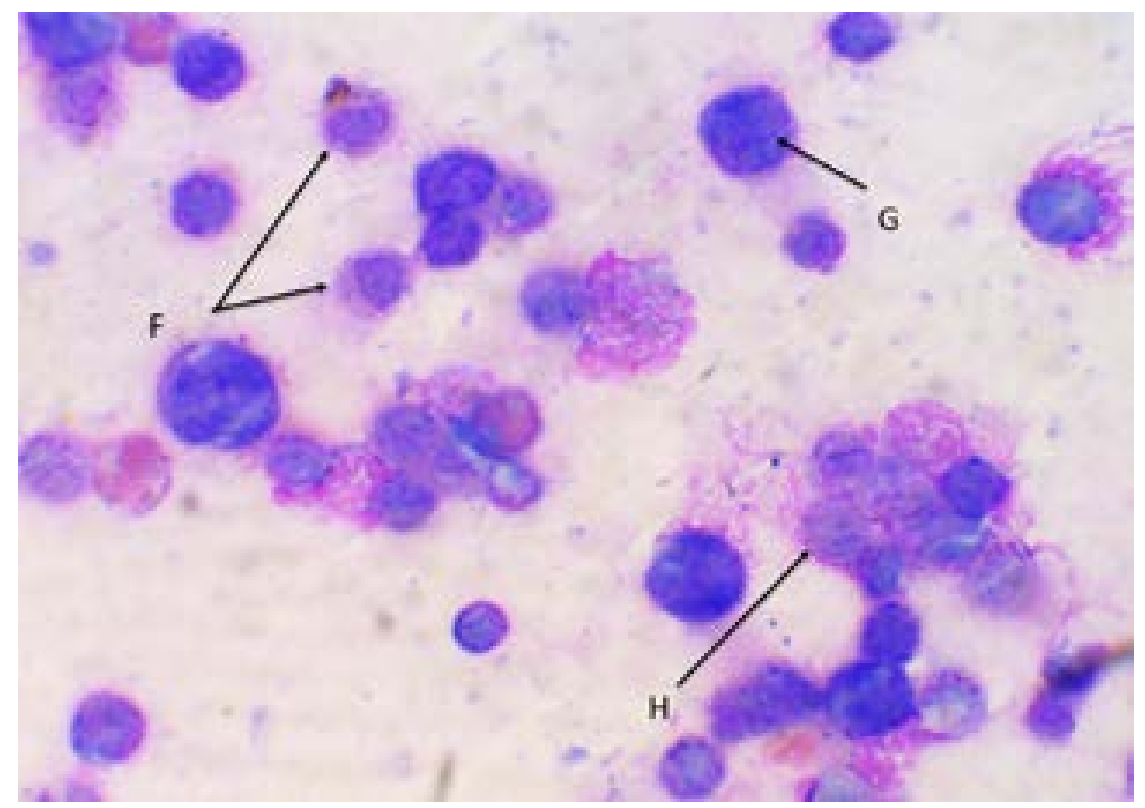

Plate 4: Bone marrow smear from RB (Wright's stain X00). RB: Rats that received $6 \mathrm{mg} / \mathrm{kg}$ bw./week of etoposide VP-16 and $200 \mathrm{mg} / \mathrm{kg}$ bw./day of extract. F. Myeloblasts. G. Erythroblast. H. Erythroblast with micronuclear fragmentation 


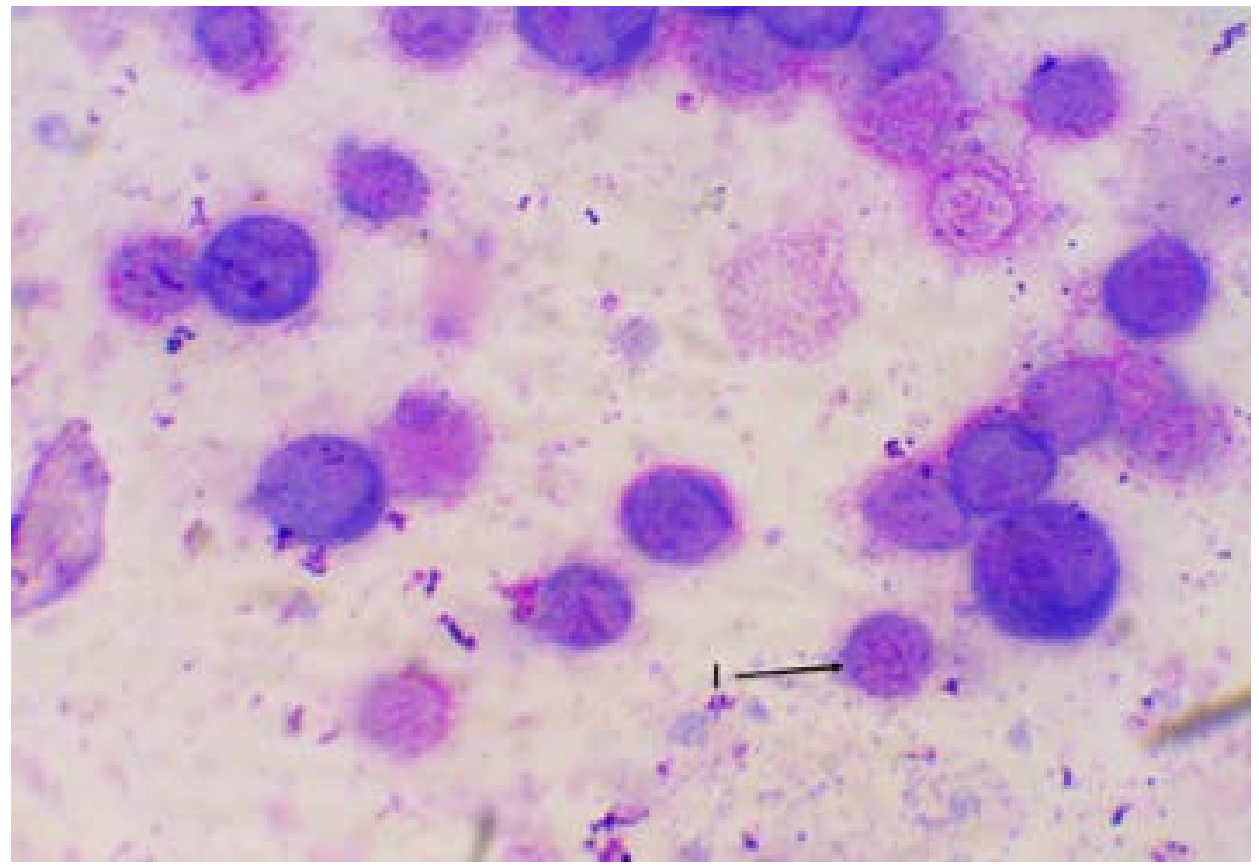

Plate 5: Bone marrow smear from RC showing myeloblast with undefined nuclear outline. RC: Rats that received $6 \mathrm{mg} / \mathrm{kg}$ bw./week of etoposide VP-16 and $300 \mathrm{mg} / \mathrm{kg}$ bw./day of extract. I. Myeloblast with undefined nuclear outline.

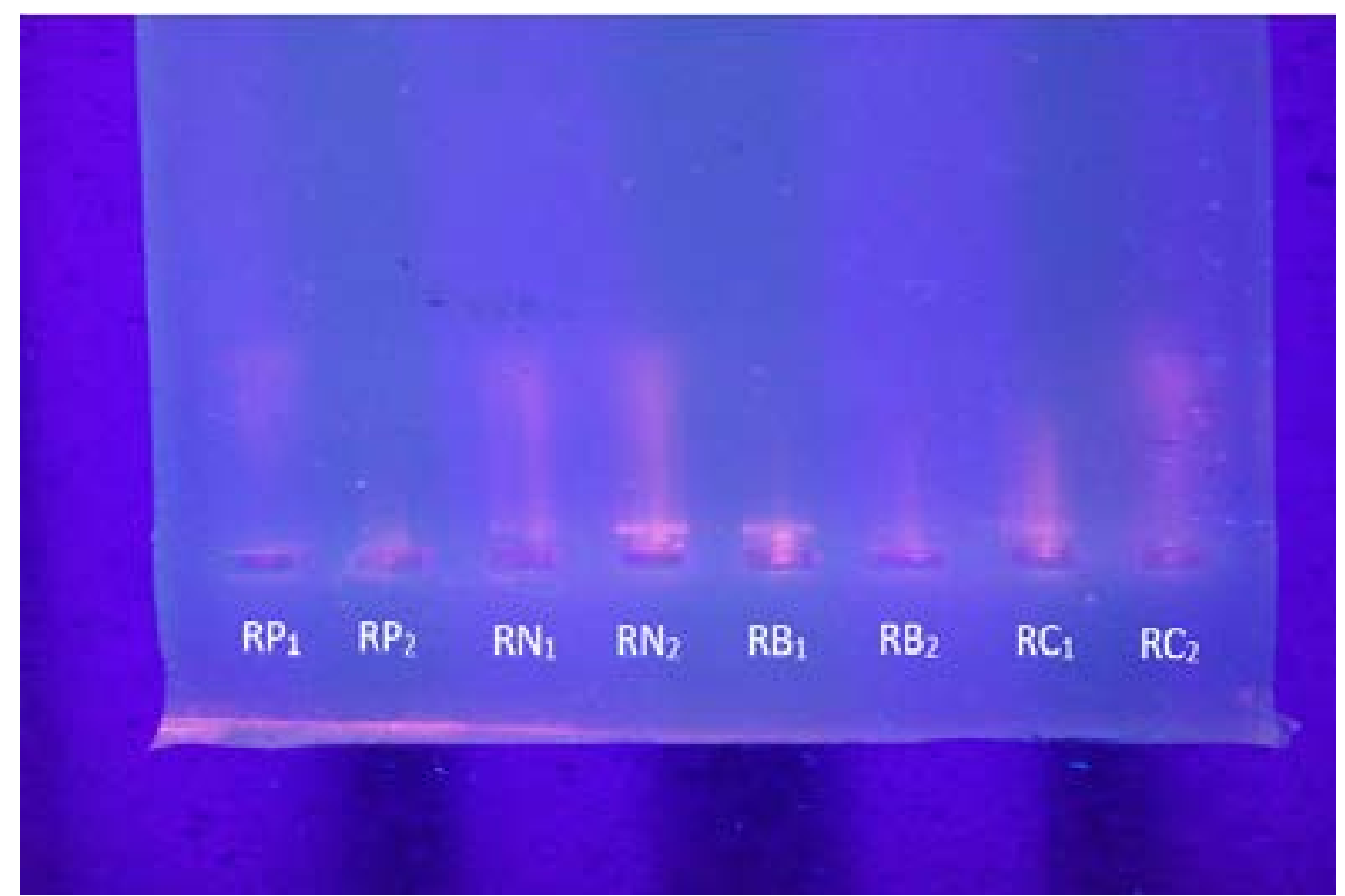

Plate 6: Agarose gel electrophoresis bands of extracted DNA from blood of rats. It shows slight variation in gel pattern of DNA from RN, RB and RC.

Legend: Plate 6 shows electrophoretic bands of DNAs obtained from blood cells of rats RP: (Positive control) - Rats that received distilled water only

RN: (Negative control) - Rats that received $6 \mathrm{mg} / \mathrm{kg}$ bw./week of etoposide VP-16

RA: Rats that received $6 \mathrm{mg} / \mathrm{kg}$ bw./week of etoposide VP-16 and $100 \mathrm{mg} / \mathrm{kg}$ bw./day of extract RB: Rats that received $6 \mathrm{mg} / \mathrm{kg}$ bw./week of etoposide VP-16 and $200 \mathrm{mg} / \mathrm{kg} \mathrm{bw}$./day of extract $\mathrm{RC}$ : Rats that received $6 \mathrm{mg} / \mathrm{kg}$ bw./week of etoposide $\mathrm{VP}-16$ and $300 \mathrm{mg} / \mathrm{kg}$ bw./day of extract 
There was no significant $(\mathrm{p}>0.05)$ difference observed in the complete blood count parameters (Table 3) amongst the treated groups in comparison with the positive control.

Table 3: Effects of aqueous extract of Allium sativum cloves on haematological parameters of etoposide treated rats

\begin{tabular}{lllll}
\hline Parameters & RP & RN & RB & RC \\
\hline RBC (x10 $/ \mathbf{m m}^{2}$ & $5.65 \pm 0.75$ & $0.36 \pm 0.12$ & $4.8 \pm 0.86$ & $4.2 \pm 0.04$ \\
PCV (\%) & $28 \pm 3.70$ & $23.4 \pm 6.45$ & $31.1 \pm 3.65$ & $26.9 \pm 2.55$ \\
Hb (g/dl) & $9.9 \pm 3.50$ & $8.85 \pm 3.05$ & $10.8 \pm 1.45$ & $10.3 \pm 0.85$ \\
MCV (\%) & $64.2 \pm 3.60$ & $64.80 \pm 5.00$ & $60.2 \pm 0.90$ & $62.9 \pm 5.05$ \\
WBC (x 10 $\left.\mathbf{m} / \mathbf{m m}^{3}\right)$ & $5.8 \pm 1.70$ & $6.1 \pm 1.70$ & $6.2 \pm 0.45$ & $4.4 \pm 0.65$ \\
PLT (x10 $\left.\mathbf{m m m}^{3}\right)$ & $484.9 \pm 61.50^{*}$ & $595 \pm 85.0$ & $615.2 \pm 85.00$ & $635.5 \pm 185.00^{*}$ \\
Lymphocytes (\%) & $76.8 \pm 9.65$ & $71.9 \pm 9.05$ & $81.3 \pm 0.05$ & $79.4 \pm 4.05$ \\
Granulocytes (\%) & $16.7 \pm 7.05$ & $20.1 \pm 12.30$ & $9.7 \pm 1.90$ & $12.5 \pm 2.10$ \\
\hline
\end{tabular}

Key: $\mathrm{RBC}=$ Red blood cells, $\mathrm{PCV}=$ Packed cell volume, $\mathrm{WBC}=$ White blood cells,

$\mathrm{MCV}=$ Mean cell volume, $\mathrm{HB}=$ Haemoglobin

Values are means of 3 replicates \pm SD

(*) significant change

\section{Discussion}

The evidence of erythroblast nuclear fragmentation and presence of myeloid with undefined nuclear outline seen in bone marrow smear of negative control group (RN) and treatment group (RC) was suggestive of possible early manifestations of DNA damage on the erythroid cell precursors due to etoposide administration. There were also fewer myeloid and erythroid precursor cells in the treatment groups when compared with the positive control group (RP). This was corroborated by the study done by Papiez ${ }^{24}$, reporting an initial short-term substantial decrease in the percentage of myeloid precursors and erythroid nucleated cells in bone marrow smear of rats caused by etoposide administration.

There was no significant difference between the complete blood count parameters amongst the treated groups in comparison with the positive control. This could be due to the fact that the evidence of manifestations of clinical and diagnostic symptoms of etoposide induced DNA damage leading to leukemia which is seen as abnormal blood cell counts, particularly the WBCs, develop about 2-3 years post exposure to the chemotherapeutic agent and is also largely dependent on long exposure to the drug even at sub-lethal doses ${ }^{25}$. Both conditions however were not covered in this experiment. The significant increase in the platelet count of the treated groups (RB) and RC with the most increase seen in the group that received the highest dose of extract ie $300 \mathrm{mg} / \mathrm{kg}$ bw. / day (RC) as compared to the positive control group (RP), was in contrast with
Olaniyan et al, ${ }^{26}$ who reported a non-significant change in platelet count amongst adult wistar rats treated with aqueous Allium sativum extract. This significant increase in platelet count with increase in the concentration of the extract administered may have been as a result of the combined action of etoposide and increased extract administration in this group. The slight deviation from normal displayed by bands obtained from agarose gel electrophoresis particularly with RN2 may have arisen from DNA damage caused by etoposide administration. This is in line with the report done by Berger et $\mathrm{al}^{27}$, who proposed that the imprecise repair of etoposide induced double stranded breaks through non-homologous DNA end-joining (NHEJ), results in chromosomal translocations involving cellular oncogene which induces the leukomogenic pathway a few years post exposure to the drug. The RB1 and RC1 however displayed a slight similarity with $\mathrm{RN} 2$ suggesting that the extract administered may actually not have prevented the damage done by etoposide. This may be due to the reported mechanism of action of Allium sativum extracts. In the study done by Lamm and Riggs ${ }^{21}$, it was reported that Allium sativum metabolites induce apoptosis in leukemic cells through the mitochondria-dependent caspase cascade which causes a significant reduction of anti-apoptotic $\mathrm{Bcl}-2$ that results in the release of cytochrome $\mathrm{C}$ and the activation of caspase- ${ }^{3}$ ${ }^{28}$. The proprietary aging process produces an odourless preparation and converts the harsh, unstable organosulphur compounds in garlic (e.g allicin) into milder and more beneficial compounds which are responsible for the anticancer effects of Allium sativum ${ }^{29}$. Johnson 
and Yedjou ${ }^{20}$, reported a free radical activity and a direct cytotoxic effect on cancer cells particularly leukemic cell lines. The anti-leukaemic properties of Allium sativum have been attributed to its sulphur containing metabolic by-products which are formed on crushing and long standing from its major phytochemical allicin. Allicin and its metabolites reportedly induce apoptosis in leukemic cells through the mitochondria-dependent caspase cascade which causes a significant reduction of the anti-apoptotic Bcl-2 that results in the release of cytochrome $\mathrm{C}$ and activation of caspase- ${ }^{321}$.

\section{Conclusion}

The study showed that aqueous extract of fresh Allium sativum cloves may not be the option for the prevention of etoposide induced leukemia in rats since the bone marrow smears showed that the plant extract did not prevent erythroblast fragmentation which may be indicative of existing DNA damage following etoposide treatment.

\section{Acknowledgements}

We are grateful to the laboratory staff of Cell Biology and Genetics of the University of Lagos, Nigeria.

\section{References}

1. Elisabetta M, Patrizia C, Luca L, Federica S, Sabrina $G$, Andrea B, Giuseppe L, Simona S. Allogeneic Hematopoietic Stem Cell Transplantation In Therapy-Related Myeloid Neoplasms (t-MN) of the Adult: Monocentric Observational Study and Review of the Literature. Mediterranean Journal of Hematology and Infectious Diseases. 2018; 10(1).

2. Brunning, RD, Matutes E, Flandrin G. Acute myeloid leukaemias and myelodysplastic syndromes, therapy related. In: Jaffe ES, Harris NL, Stein H, et al., editors. World Health Organization Classification of Tumours: Pathology and Genetics of Tumours of Haematopoietic and Lymphoid Tissues. Lyon: LARC Press. 2001; pp. 89-91.

3. Godley LA, Larson R A. The syndrome of therapy-related myelodysplasia and myeloid leukemia. In: Bennett JM, editor. The myelodysplastic syndromes: pathobiology and clinical management. New York: Marcel Dekeker, Inc. 2002; pp. 139-76.

4. Offman J, Opelz G, Doehler B. Defective DNA mismatch repair in acute myeloid leukemia/myelodysplastic syndrome after organ transplantation. Blood. 2004; 104:822-28.

5. Rowley JD, Olney HJ. International workshop on the relationship of prior therapy to balanced chromo- some aberrations in therapy-related myelodysplastic syndromes and acute leukemia: overview report. Genes Chromosomes Cancer. 2004; 33:331-45.

6. Smith A, Howell D, Patmore R. Incidence of haematological malignancy by sub-type: a report from the Haematological Malignancy Research Network. British Journal of Cancer. 2011; 105:1684.

7. Bhatia S. Therapy-related myelodysplasia and acute myeloid leukemia. Seminars in Oncology. 2013; 40 (6): 666675.

8. Granfeldt Østgård LS, Medeiros BC, Sengeløv H, Nørgaard M, Andersen MK, Dufva, IH, Friis, LS, Kjeldsen E, Marcher CW, Preiss B, Severinsen M, Nørgaard JM. Epidemiology and Clinical Significance of Secondary and Therapy-Related Acute Myeloid Leukemia: A National Population-Based Cohort Study. Journal of Clinical Oncology. 2015;1:33(31):3641-9.

9. Govindarajan R, Jagannath S, Flick JT, Vesole DH, Sawyer J, Barlogie B, Tricot G. Preceding standard therapy is the likely cause of MDS after autotransplants for multiple myeloma. British Journal of Haematology. 1996; 95(2):349-53

10. Pedersen-Bjergaard J, Pedersen M, Myhre J, Geisler C. High risk of therapy-related leukemia after BEAM chemotherapy and autologous stem cell transplantation for previously treated lymphomas is mainly related to primary chemotherapy and not to the BEAM-transplantation procedure. Lenkemia. 1997; 11(10):1654-60.

11. Milligan DW, Ruiz De Elvira MC, Kolb HJ., Goldstone AH, Meloni G, Rohatiner AZ, Colombat P, Schmitz N. Secondary leukaemia and myelodysplasia after autografting for lymphoma: results from the EBMT. EBMT Lymphoma and Late Effects Working Parties. European Group for Blood and Marrow Transplantation. British Journal of Haematology. 1999; 106(4):1020-26. 12. Krishnan A, Bhatia S Slovak ML, Arber DA, Niland JC, Nademanee A, Fung H, Bhatia R, Kashyap A, Molina A, O’Donnell MR, Parker PA, Sniecinski I, Snyder DS, Spielberger R, Stein A, Forman SJ. Predictors of therapy-related leukemia and myelodysplasia following autologous transplantation for lymphoma: an assessment of risk factors. Blood. 2000; 95(5):1588-93.

13. Wheeler C, Khurshid A, Ibrahim J, Elias A, Mauch P, Ault K, Antin J. Incidence of post-transplant myelodysplasia/acute leukemia in non-Hodgkin's lymphoma patients compared with Hodgkin's disease patients undergoing autologous transplantation following cyclophosphamide, carmustine, and etoposide (CBV). Leukemia and Lymphoma. 2001; 40(5-6):499-509.

14. Gilliland DG, Gribben JG. Evaluation of the risk of therapy-related MDS/AML after autologous stem cell 
transplantation. Biology of Blood and Marrow Transplantationl. 2002; 8(1):9-16

15. Link DC, Schuettpelz LG, Shen D, Wang J, Walter MJ, Kulkarni S, Payton JE, Ivanovich J, Goodfellow PJ, Le Beau M, Koboldt DC, Dooling DJ, Fulton RS, Bender RH, Fulton LL, Delehaunty KD, Fronick CC, Appelbaum EL, Schmidt H, Abbott R, O'Laughlin M, Chen K, McLellan MD, Varghese N, Nagarajan R, Heath S, Graubert TA, Ding L, Ley TJ, Zambetti GP, Wilson RK, Mardis ER. Identification of a novel TP53 cancer susceptibility mutation through whole-genome sequencing of a patient with therapy-related AML. Journal of American Medical Association. 2011; 305(15):156876.

16. Schulz E, Valentin A, Ulz P, Beham-Schmid C, Lind K, Rupp V, Lackner H, Wölfler A, Zebisch A, Olipitz W, Geigl J, Berghold A, Speicher MR, Sill H. Germline mutations in the DNA damage response genes BRCA1, BRCA2, BARD1 and TP53 in patients with therapy related myeloid neoplasms. Journal of Medical Genetics. 2012; 49(7):422-428.

17. Danielle T, Sunelle R, Namrita L. "Are medicinal plants effective for skin cancer?" Medicinal plants for $\mathrm{Ho}$ listic health and wellbeing. 2018; 2:13-75

18. Soforowa A. Medicinal Plants and Traditional Medicine in Africa. Chichester John, Willey and Sons, New York. 1993; p. 256

19. Chris-ozoko LE, Naiho AO, Okeke F. Histological Effect of Aqueous Garlic (Allium Sativum) Extract on the Testis and Ovary of an Adult Wistar Rat. Journal of Dental and Medical Sciences. 2016; 15(1): 38-45

20. Johnson K, Yedjou C. "Cytotoxic efficacy and inhibitory effect of garlic extract to human leukemia (Hl60) cells," in Proceedings of the $10^{\text {th }}$ International Symposium on Recent Advances in Environmental Health Research. 2013
21. Lamm DL, Riggs DR. Enhanced immunocompetence by garlic: role in bladder cancer and other malignancies. Journal of Nutrition. 2001; 131(3s):1067S-70S. 22. Papież MA, Krzyściak W, Szade K, Bukowska-Straková K, Kozakowska M, Hajduk K, Bystrowska B, Jozef Dulak J, Jozkowicz A. Curcumin enhances the cytogenotoxic effect of etoposide in leukemia cells through induction of reactive oxygen species. Drug Design, Development and Therapy. 2016;10: 557-70

23. Whitlock JA, Greer JP, Lukens JN. Epipodophyllotoxin-related leukemia: Identification of a new subset of secondary leukemia. Cancer. 1991; 68: 600-4.

24. Papiez, M. A. The effect of quercetin on oxidative DNA damage and myelosuppression induced by etoposide in bone marrow cells of rats; Acta Biochem Pol. 2014;61 (1): 7-11

25. Josting A, Wiedenmann S, Franklin J. Secondary myeloid leukemia and myelodysplastic syndromes in patients treated for Hodgkin's disease: a report from the German Hodgkin's Lymphoma Study Group. Journal of Clinical Oncology. 2003; 21:3440-46.

26. Olaniyan OT, Meraiyebu AB, Arogbonlo A, Dare JB, Shekins O, Shafe MO. Effects of Aqueous Extract of Garlic (Allium sativum) on Blood Parameters in adult Wistar rats. International Journal of Pharmacentical Science Invention. 2013; 2(3):42-45

27. Berger A, Chatterjee JA, Schmotzer C, Helms SR. Etoposide (VP-16-213)-induced gene alterations: Potential contribution to cell death. Proceedings of the National Academy of Sciences of the United States of America. 1991; 88:8740-43.

28. Lamm DL, Riggs DR. Enhanced immunocompetence by garlic: role in bladder cancer and other malignancies. The Journal of Nutrition. 2001; 131:1067-70.

29. Thomson M, Ali M. Garlic [Allium sativum]: A Review of its Potential Use as an Anti-Cancer Agent. Curr Cancer Drug Targets. 2003; 3: 67-81 